\title{
Children Of Men (2006): Representation of Modern Spirituality in an Apocalyptic Dystopian World
}

\author{
Mulya Cindi Ovira Lestari ${ }^{1}$, Bayu Kristianto ${ }^{2}$ \\ ${ }^{[1]}$ Universitas Indonesia \\ Jakarta, Indonesia \\ Email: mcovira@gmail.com \\ ${ }^{[2]}$ Universitas Indonesia \\ Jakarta, Indonesia \\ Email: baladewabayu@gmail.com
}

\begin{abstract}
In the post-industrialization era, spirituality has gone through many shifts. Specifically, perceptions of spirituality have changed for the worst after $9 / 11$, which inspired several movies in portraying spirituality within the society in science fiction movies. Children of Men (2006) is one of science fiction movies that portray biblical apocalyptic narratives in which spirituality is a crucial element in the movie, indicating how influential spirituality is in popular culture. This research paper aims to analyze how modern spirituality is represented through the shift from Weber's concept of disenchantment to Jenkin's concept of re-enchantment, examining how it affects oneself in the biblical apocalyptic narrative. The representation is analyzed by focusing on a huge alteration that resulted from the attack of 9/11, which affects how the disenchanted society in the movie deals with the gloom of apocalypse. These responses lead to re-enchantment as the movie incorporates biblical allegories that represent hope for tomorrow, which is fundamental teaching for most religions.
\end{abstract}

Keyword: Modern Spirituality, Disenchantment, Re-Enchantment, Apocalypse.

\section{INTRODUCTION}

"Beloved, now are we the sons of God, and it doth not yet appear what we shall be: but we know that, when he shall appear, we shall be like him; for we shall see him as he is" (1 John 3:2, The New King James Version).

The future is uncertain, yet for centuries, some people have been trying to be aware of the consequences of their actions out of fear of the apocalypse. There are a lot of narrations of apocalypse in religious books throughout history, and their relevance has been more apparent today along with the rise of pop-culture, including science fiction. As stated by Swartz (2009), several postapocalyptic science fiction movies are inspired by the biblical apocalyptic scenario with the same appeal; those who survive are the ones who are faithful. Children of Men (2006), a science fiction movie that is heavily influenced by the September 11 attacks (also known as 9/11), shares the same narrative. The premise of this movie is simple; it is about saving mankind from extinction in the hands of a refugee who miraculously got pregnant after 18 years of infertility has spread in the entire world. However, what goes beyond the premise is the representation of spirituality in such an apocalyptic dystopian world and its connection with today's society. As stated by Alfonso Cuarón, the director of the movie, "the future isn't someplace ahead of us; we're living in the future at this moment,"; thus, it is clear how the connection is not imaginary anymore (2016).

The year of 2027 in the movie is illustrated in visual realism; there are no exaggerated aspects that successfully encode the future into our mind as something close and imaginable because of how familiar it is. The clothes are similar to what the people of Britain would usually wear in winter today, without built-in wings or silver and shiny outerwear. The buildings are also the same; there are no unrealistic landscapes like the ones pictured in futuristic films such as Blade Runner (1982) and Avatar (2009). However, it is implied how the year of 2027 is allegedly very modernized from how the post-industrialization society is shown in the movie through advanced technology and weaponry, which seems to be one of the many causes of infertility for the past 18 years. Thus, the movie will be examined from a concept that is stated by Max Weber in a lecture in 1918 about modernity as a disenchantment 
of the world that abandons religion and superstitions as a product of science and rationalization. Advanced machinery and rapid growth of technology are aligned with the notion that everything has a scientific explanation, which is in line with Weber's concept of disenchantment stated before. Modern society no longer thinks that the Earth is the center of the universe, and to understand the concept of heliocentric is a big sign of an advanced civilization to study phenomena in nature complete with empirical evidence. However, how about what goes beyond science, such as spirituality and religion? This is where the re-enchantment of the world and its role can be felt in today's society and is depicted in the movie's dystopian world.

As religion is a quite prominent theme in the movie, several articles have been written from a religious perspective by scholars. Primarily focusing on sound and music, Hamner (2015) stated that sensing religion in Children of Men through affective religious modalities such as "nostalgic" and "emergent" signals the sacred and transcendence in the movie. Another article mentioned how Christian theological symbols in the movie offers a new kind of Messianic connotation by implying that plurality could save humanity from destruction (Schwartzman, 2009). Contrary to the two previous research articles, O'Donnell (2015) found a different perspective on the apocalyptic narrative in the movie, mentioning how it reflects political reality instead of a biblical apocalyptic allusion. In an article written by Julia E. Domingo, it is discussed how liquid fear like epidemics and immunological fearin regards of terrorism and migration issues - in the movie constructs a liquid space and time through the visual language of the long take and intertextual references, referencing to how the fear could easily spread across borders (2015). Another article discussed how materiality captures race as a material reality in which allegory in the movie is understood as a figure for reorganizing the issue of racial alterity as a materialist concern (Chaudary, 2009). Regardless of the number of research that is focusing on the religious aspect of the movie, analyzing modern spirituality in the movie using Weber's concept of disenchantment and its connection with re-enchantment has not been done yet.

The purpose of using this concept to analyze modern spirituality is to understand the position of spirituality in the brink of an apocalypse. Therefore, the aims of this research lie in how disenchantment and re-enchantment are represented in the movie which displays their functions and meanings in modern post-apocalyptic society. The first thing to be analyzed is the contextual background of a disenchanted society related to $9 / 11$, as religion is not perceived the same as it was in the past anymore. Later on, this paper will discuss the characters and their relationship to disenchantment and re- enchantment. It will discuss the response of modern spirituality and the narration on religion built in the movie. Another prominent element that will also be examined is symbolism in the movie that represents ideas and meanings the film tries to convey and its embodiment of modern spirituality in the dystopian last-man-standing generation.

\section{THEORETICAL FRAMEWORK}

\section{Disenchantment}

In Sociology of Religion (1963), Max Weber described how a post-industrialization modernized characteristic is a vital subject of disenchantment concept, where the characteristics of modernized, bureaucratic, secularized Western society, along with the rise of technological development and scientific explanations are things that are more valued and preferable than belief. Furthermore, disenchantment somehow aligns with secularism which Cambridge dictionary describes as "the belief that religion should not be involved with the ordinary social and political activities of a country" ("Secularism", 2019). Even though the two are different, both concepts reject religion as an instrument of social control. They share similar ideas about how religion bears no meaning, or even brings harm to society. Besides, Charles Taylor, the author of A Secular Age (2007), argues that science and technology are not the cause of why people slowly lose their faith as the underlying reasons are far more complex due to changes from people's perspectives on religion that have transformed in modern times.

\section{Re-enchantment}

Re-enchantment emerges as the complexity of postmodern society involves something not only advanced technology but also advanced thinkers behind it. The argument on how religion and spirituality is a feasible choice parallels to modern spirituality. People are free to choose between believing and not believing. Also, it is inevitable to talk about the desecularization of the seemingly secularized society, as affirmed by Peter L. Berger et al. (1999) in a book titled The Desecularization of the World: Resurgent Religion and World Politics. According to Berger, contradictory to secularism, religion will always be relevant in the modern world, including in post-apocalypse narrations. Religion is much more complex than it seems to be because religion has become so powerful yet so dangerous, as stated by Mark C. Taylor in his book After God (2007). The shift in spirituality also affects how biblical allegory in the movie does not depict religion itself, but the effect of susceptibility that triggers hopefulness in a modern world (Hamner, 2015). 


\section{ANALYSIS}

\section{Disenchanted Society}

The depiction of futurism is aligned with Weber's concept of disenchantment of the world as stated in his book. Inferring disenchantment as a lack of sympathy, a negative perception towards religion, a dismissal of art and culture, and heavy promotion of scientific explanations behind everything suggests how the society portrayed in the movie has been disenchanted from the world since a long time ago (Weber, 1963).

First of all, taking references from the 9/11 religious allegory in the movie, it does not only show how pessimistic the world can be, but it also mirrors how the society reacts to its number one suspected culprit that is religion as shown at the beginning of the movie,

Day 1,000 of the Siege of Seattle. The Muslim community demands an end to the Army's occupation of mosques. The Homeland Security bill is ratified. After eight years, British borders will remain closed. The deportation of illegal immigrants will continue. Good morning. Our lead story. The world was stunned today by the death of Diego Ricardo, the youngest person on the planet. Baby Diego was stabbed outside a bar in Buenos Aires after refusing to sign an autograph (00:00:33-00:01:02).

The voiceover from the newscasters reveals two different issues with a fair share of adversity; the first one is a chain of bad news that is read in an emotionless way. The way the newscasters deliver the information sentence per sentence is merely to present matters of facts. The cinematography is also just a plain pitch black screen that shows zero emotion. In this scene, the newscasters themselves are not present; it shows how unimportant this particular information is for the people. A review on The Village (2004) in theguradian.com mentioned that the depiction of fear and anxieties of a certain religion in post 9/11 Hollywood movies also results in xenophobia as America is obsessed with unseen foreign terrorists, and that is exactly how the news is depicted in Children of Men, although the setting is in Britain (French, 2004).

Besides, as the newscasters continue, the news of the death of the youngest person on Earth dearly nicknamed Baby Diego is presented with a strong sense of emotion. "Good morning, our lead story," the tone shifts to be more melancholic and woeful. The way the media and people, in general, gave a celebrity-like status to Baby Diego - shown by how people demand that he give an autograph - speaks so much about the contrast between the two kinds of news abovementioned. Besides, the scene also shows how people gather and give all of their attention to the television, which differs from how they respond to the previous news. Weeping and sobbing can also be heard, with sad expressions painted on the people's faces (00:01:39). In the back of the crowd, the visual of the news is also present, with pictures of Baby Diego rolling from slide to slide. The decrease of the society's will to live drives them away from religion, indicated by how normal advertisements for self-euthanasia kit called Quietus are in the movie. It drifts them away from religion as spirituality involves something greater than us as human beings, and to what extent we believe in our significance in the universe, according to Spencer (2012). The advertisements themselves can be seen everywhere in the movie, symbolizing how the government advertised the suicide kits which contradicts the fundamental purpose of religion.

Lastly, a huge sign of disenchantment in the movie can be seen from how an authoritarian government heavily regulated citizens' lives (Woolley, 2014). The decrease of humanity is shown in how the British government is very proud of making Britain one of the few countries with a functioning government, as shown in an advertisement broadcasted on a television in a bus, "The world has collapsed, only Britain soldiers on" (00:03:46). The advertisement continues with how the government encourages British residents to report illegal immigrants and that to shelter them is an act of crime, whether they are colleagues or family members. It presents how the government lacks sympathy and empathy, which is also exhibited through the mistreatment of immigrants by capturing them in cages, regardless of the colors of their skins (00:04:36). These selfish characteristics of the government further illustrate a disenchanted society that is fascist and oppressive, and they somehow reflect current American government policy on illegal immigrants after Brexit and the rise of Donald Trump (Riesman, 2016). It is portrayed in the scene where Theo, the main character, asks his cousin to issue transit papers so that Kee, a refugee who miraculously got pregnant after 18 years of infertility in the world, could pass the security checkpoint to get to the coast (00:20:00). Nigel, Theo's cousin who is also a high-ranking government official, manages the government's program called "Ark of Arts," which hoards and rescues valuable artworks such as Michelangelo's David, Pablo Picasso's Guernica, and Banksy's British Cops Kissing. The broken leg of the very famous David sculpture (00:18:28) and a huge piggy-bank floating in the air (00:20:40), shown in the film are symbols for capitalistic and bureaucratic notions; those who could save the invaluable artworks are the powerful ones. As stated by Domingo (2015, p. 145), the piggy-bank implies George Orwell's Animal Farm (1945) and Pink Floyd's album titled Animals (1977) in which the author and singer criticize both communist and capitalist governments using a narrative in the form of a pig to demonstrate unequal and unjust 
treatments in the society. Disenchantment can also be seen from how Alex, the son of Theo's cousin, seems to be uninterested in his surroundings and his medication pill, as his gaze is fixed on a very advanced gadget that resembles a handheld video game console that occupies all of his fingers (00:20:11). These characteristics of disenchantment display how the non-believers respond to the apocalypse.

\section{Re-enchanted Society}

As seen from the previous subchapter, the general post-apocalyptic society in the movie is seemingly very disenchanted and pessimistic. There is one scene in particular that affirms how powerful religion is, and it is quite contradictory to the disenchantment framework. In one scene, protesters state, "Earthquakes, pollutions, disease, famine. Our sins have encouraged God's wrath" (00:17:06). This particular scene of protesters in yellow trench coats, voicing out their views on procreation, human sins, and humans' infertility, shows how they still want to reconnect with the world and to save mankind from extinction through their faith. In the background, there is a huge text which declares "Infertility is God's Punishment." The notion of mankind, especially women, existing to procreate has been stated in many religious books, including in the Bible. Verses that talk about procreation such as Psalm 127:3 and Genesis 1:28 (The New King James Version), give a sense of how important it is to give birth, and the protesters try to emphasize that infertility results from humans' wrongdoings. The scene shows how the 'old-fashion' religion bounces back. Religion is still a dominating tool that strongly encourages people to do things beyond the imaginable. This is where spirituality evolves into a new form: a liberating force.

Emphasized by the word "repent" written on the front of the protesters' trench coats (00:17:08), reflecting on past mistakes is strongly encouraged to revive humanity. It may be underestimated by some modern individuals, yet the meaning of "repent" reflects how some people encourage individual to be more religious, as they believe it will revive humanity by considering the reasons why-infertility happened in the first place, maybe because of radiation from atomic war to pollutions from factories. These reasons, in other words, are the sins that the protesters try to contemplate together with the general public, which is also a highlight of reenchantment. According to Cambridge Online Dictionary, repent means "to be very sorry for something bad you have done in the past and wish that you had not done it," and such a concept can be found in several religions such as tawbah in Islam's Quran, in Buddhism, and even in an extreme doctrine of repentance based on the Christian Bible. As defined by Berger in his book, religion is too significant to ignore, including in contemporary analysis that involves people, culture, and their affairs as they are strongly interconnected (Berger et al., 1999).

Another element that represents postapocalyptic spirituality can be seen from several symbols, one of which is the birth of the first baby in 18 years. In one scene (01:31:25-01:34:04), we can see Theo and Kee protecting the baby from the ongoing fight between the rebels and the British army while heading to the ship that belongs to the Human Project, a group that devotes themselves to saving humanity from extinction. There are a lot of gunshots in the background, yet the baby's cries are loud and clear. The cries are not only enchanting the residents in the building where the battle is taking place, the rebels and the army even stopped their battle for a moment. The scene shows how countless civilians fall, yet the battle only stops when one of the soldiers yells after hearing the cries, "Stop! Ceasefire! Cease firing! We've got two coming through, coming out" (01:32:43). Civilians, soldiers, and rebels, together they are chanting their prayers to welcome the newborn into the world, uniting through different praying gestures. For a moment, the world becomes very peaceful - almost heavenly_with the angelic yet full of despair music by John Tavener titled "Fragments of a Prayer" (2006). All eyes follow every inch of Kee's moves, knowing that she is holding the world's new hope in her arms. The world seems to be full of faith and hopefulness, only to be broken by the sound of a bazooka which signals the restart of the combat (01:34:05).

Although the battle keeps going and even the presence of the baby seems to be meaningless, the hope of tomorrow is still very prominent in the movie, as shown by the ship that belongs to the Human Project, which sails in a disguise of a fishing boat called "Tomorrow." Near the end of the movie, Kee finally finds what she and Theo have been looking for to revive humanity, even though it costs their lives (01:40:00). Since the beginning, their faith unites them to finally able to reach this once-a-myth boat. As stated in Jeremiah 29:11, "For I know the plans I have for you, declares the Lord, plans for welfare and not for evil, to give you a future and a hope," there will always be a reward for those who hold on to their faith and to believe in tomorrow. In the movie, the hope for tomorrow not only represents the day after today, but it carries a deeper meaning on one's assurance in this universe. The boat itself has a symbolic meaning that represents a new beginning, as affirmed in a book titled The Language of Art: Studies in Interpretation by Moshe Barasch (1997). According to Barasch, in most early Christian literature, a boat shares a metaphorical meaning that symbolizes salvation and redemption, one of which is depicted in the story of Noah. In both Noah's story and Children of Men, the ark 
symbolizes a safe place for mankind to redeem their sins. Also, ships often become a metaphor for the church and those who believe in God's guidance, similar to how the boat can save Kee in the end. The boat can be interpreted as a new journey after humans contemplate their mistakes in the past. This is also implied by the epilogue of the movie (1:40:18), where the scene turns black again just like in the beginning but shares different connotations. When the title "Children of Men" appears, there is children's laughter in the background, denoting a sign that humanity has been revived once again. The children's laughter also strengthens the sense of faith for tomorrow repeatedly stated in this paragraph.

Re-enchantment, however, has taken another form in this dystopian world, as spirituality has altered greatly after the 9/11 event. In today's world, spirituality can be understood from how religious devotees perceive religion as something to live for, something to die for, and occasionally something to kill for (Healey, 2005). In the scene where Muslim immigrants take the street of Britain's border (01:20:58), the armed Islamic militants chant "Allahu Akbar," which means "God is great" in Arabic, implying a more negative connotation of religion. The phrase has become synonymous with visions of religious extremism and violence after several attacks that occurred with the perpetrators shouting "Allahu Akbar," one of which happened during a truck-ramming attack in Manhattan on October 31, 2017, resulting in the death of eight people (Callahan, 2017). On the other hand, no matter how destructive religion can be, which sometimes includes political interests, it is still a form of re-enchantment. In the movie, spirituality is not only a limited understanding of religion put into boxes but also a fusion of everything, whether it is negative or positive. Religion as a strong influence is not only a way to find peace within oneself, but it can also be a dangerous and powerful tool that affects the society greatly, no matter how modernized it is, as stated in a book titled After God (2007):

You cannot understand the world today if you do not understand religion. Never before has religion been so powerful and so dangerous. No longer confined to church, synagogue, and mosque, religion has taken to the streets by filling airways and networks with images and messages that create fatal conflicts, which threaten to rage out of control. When I began pondering these issues in the 1960s, few analysts or critics would have predicted this unexpected turn of events (Taylor, 2007, as cited in Walton, 2011).

Then again, the powerfulness of religion has influenced people's lives since the beginning of human history. Mankind always tries to correlate mysterious phenomena with what seems rational for them. Spirituality and religion are two of many attempts in comprehending these events, including the concept of the apocalypse that is still relevant in a far more advanced world that is depicted in the movie.

\section{Modern and Post-Apocalyptic Spirituality within the Characters}

Each character of the movie represents a variety of complex characteristics that portray the mixture of modern spirituality and post-apocalyptic spirituality. In this part of the analysis, the characters will be analyzed by focusing on cinematic devices such as dialogue and two elements of mise-en-scène: setting and the behavior of the characters (Bordwell \& Thompson, 2003).

\subsection{Theo Faron: Vulnerability to Spirituality}

This character's transformation is a perfect example that depicts the shift from disenchantment to reenchantment. As briefly mentioned in the first subchapter of this paper; he is a cold, apathetic character who cannot be more careless about the death of Baby Diego. His character is being portrayed as a pessimist that lives a mundane life, waking up to go to work, grabbing his coffee, and pouring his alcohol in the morning. His meeting with his ex-wife, Julian, during which she asks for a favor from him in exchange for money (00:15:09), only proves how disenchanted he is from the world. His cynical nature embodies the change from once an activist to become a pessimist after the death of his child, significantly decreasing his will to live and desire to reconnect with the world. What makes his character seem very detached is how he mourns for the loss of his and Julian's child. While Julian copes with it and keeps moving forward, shown by how she fights for justice for immigrants, Theo mismanages the loss by drinking. Described as a reluctant hero by a few movie critics in Rottentomatoes.com, the scene where Kee asks for Theo's help illustrates how unwilling he is to sympathize with others, "The Tomorrow? I don't know what you're talking about, but I'm sure your friends can take care of you" (00:36:00).

As an unwilling hero, he seems very distant from other people, yet he is still labeled as a "hero." The label is plastered to him as his thoughts are changed after Kee reveals that she is pregnant (00:36:15). As a disenchanted character, the alteration of Theo's spirituality can be seen from where the conversation takes place, a barn full of cows and milking machines. It strongly refers to the birth of Jesus and the enlightenment that comes within, and is interpreted as referring to one verse in the Bible:

"...Joseph son of David, do not be afraid to take Mary home as your wife, because what is conceived in her is from the Holy Spirit. ${ }^{21}$ She will give birth to a son, and you are to give him the name Jesus because he will save 
his people from their sins" (Matthew 1:20-21,

The New International Version).

Theo may not become Kee's husband; however, the scene denotes how Theo changes his mind gradually. The enlightenment is shown by how his eyes widen (00:36:55). His face changes from the usual stoic one to an expression that is full of emotion. If he were still the apathetic person he was before, he would not bat an eyelid for it, yet he tries to protect Kee the best he can even though his life is on the line. His death in the latter part of the movie (01:39:08) also represents a reoccurring theme that is sacrifice. It is not because he lost his will to live, but he is holding on to his faith to cure infertility which he believes will be able to resuscitate mankind from extinction. The subtlety of his spirituality may differ from that of the other characters, but it does occur to him that his spirituality enables him to develop a sense of meaning. His spirituality, however, has altered from the ordinary spirituality to the complex one, as the Christian theological symbols in the movie do not refer to him as a religious being, but rather as a mirror of today's society in the brink of an apocalypse, as stated by M. Gail Hamner:

The film uses effect and religion not to show conversion or sanctification but rather to evoke a mode of transcendence that reminds us how attentive care for life in general (the species, the globe) must at some point or by some bodies exceed and frame our daily cares, and to elicit the conviction that hopeshuman and political — can emerge only from the sheer fact of ontological vulnerability. Religion in Children of Men is not used to convey doctrine or salvation but rather to convey the sears and jolts of the effect that transverse the structure of feeling of our near future, and percolate toward structural mediations of some new affective landscape (2015, pp. 1452-1453).

From Theo, it can be inferred that unlike religions from the pre-industrialization era, post-apocalyptic spirituality does not define how religious a person is, but rather how vulnerability makes us human and triggers hope and optimism. Unlike other characters, his spirituality has never been explicitly shown throughout the movie, which can be inferred that spirituality has become more complex and dynamic.

\subsection{Kee: Faithful Endeavors Leading toward Re-} enchantment

Kee is a refugee who symbolizes hope for the future and faith, which makes her even more special because of her marginalized background. The conversation between Kee and Theo, in which Kee responds to Theo: "Fuck knows, I don't know most of the wankers' name" (00:51:25) shows how she as a refugee from West Africa exemplifies a demoted yet substantial character. Originally, Kee does not even exist in P.D James' Children of Men (1992), yet she is the key character in the movie version. Kee's pregnancy is too miraculous - often it is depicted as something that seems like a mythos-as shown by how she refers to herself as the Virgin Mary, stated in a dialogue between her and Theo when he asks her who the father of her baby is, and she answers him jokingly, "Whiffet. I'm a virgin" (00:51:13). In the conversation, however, she talks about how her pregnancy has brought her a sense of meaning in this world:

You know, when I started puking, I thought I catch the pest. But then my belly started getting big. Nobody ever told me these things. I never have seen a pregnant woman before. But I knew. I felt like a freak. I didn't tell anybody. I thought about the Quietus thing. Supposed to be suave. Pretty music and all that. Then the baby kicked. I feel it. The little bastard was alive. And I feel it. And me, too. I am alive.

Kee, as a cheerful character, is once disenchanted from the world at one point, yet her hopefulness is revived again and is very prominent in the movie, as shown by the dialogue above. Her faith makes her stronger, even though she could choose not to hold on to her belief when she did not know what happened to her body. In the scene where Julian's dead body is left in the wood (00:31:09), she is also pictured praying with Miriam, an ex-midwife. Another piece of evidence that suggests her faith is when she always trusts Julian to find the Tomorrow boat devotedly, "But Julian said only trust you. She said you'd help me" (00:36:03). Even though the existence of the boat is almost unlikely to be trueespecially after the death of Julian - she still wants to put her endeavor in reaching the salvation, which signals how she is in pursuit of re-enchantment.

\subsection{Miriam: A Fusion of Spirituality}

The character of Miriam perfectly describes a faithful individual who strongly believes in her spirituality. Her spirituality is not only limited to one religion; it is a fusion of any kind of religion that can comfort her when the times are dark and depressing. In the scene where the rebels are conspiring to kill Julian, she is chanting her prayer, "Oh, save us! Save us in our hour of need! Blessed Mary, save us!" (00:27:59). However, as a midwife, she also shows her credibility in her used-to-be occupation, as depicted in how she tries to stop Julian's bleeding during which she says "Put pressure on the wound! Please, please, please. Please, please" (00:28:48), which also depicts how she talks about being a midwife in an old school on Watchbell Road in Rye when she, Kee, and Theo are running from the Fishes to meet Syd, a border guard whom Jasper sells his potto. 
I was 31. Midwife at the John Radcliffe. I was doing a stint in the antenatal clinic. Three of my patients miscarried in one week. Others were in their fifth and sixth month. We managed to save two of the poor babies. Next week, five more miscarried. Then the miscarriages started happening earlier. I remember booking a woman in for her next appointment and noticing that the page seven months ahead was completely blank. Not a single name. I rang a friend who was working at Queen Charlotte's, and she had no new pregnancies, either. She then rang her sister in Sydney. And it was the same thing there.... As the sound of the playgrounds faded, the despair set in. Very odd what happens in a world without children's voices. I was there at the end. Yeah, I'll be there at the beginning (01:01:48-01:03:12).

In the scene, she reminisces how uncertain the future is when infertility has swept the entire world. She is probably amongst the first person who notices the doom through her profession, and her spirituality is something that helps her to stand on her feet again. Her personality is very optimistic, as shown by how she is very positive about how she will be one of the first witnesses of a miracle that is Kee's baby.

Another scene that portrays Miriam's spirituality is when she performs a ritual in Jasper's house, in which Theo and Kee shares conversation about it:

Kee: "Is she doing her voodoo hoodoo?"

Theo: "She's doing something." Kee: "She smote me with that. Said it was good for my baby. Does she look posh to you, or gawky?" Theo: "Earnest" (Kee laughs) (00:50:36).

Despite being a mid-wife, Miriam shows how important her spirituality is to her, no matter how she appears "gawky," defined by Merriam-Webster dictionary as "awkward," to the people around her. Her spirituality depicts how shamanic practices such as Father Christmas ritual-which can be traced back to its origin in Lapland and Siberia-has been applied by Westerners to promote spirituality and therapeutic practices within themselves, as stated by Black (2010). Another important scene that portrays her spirituality is when she chants her prayers in front of a British soldier who gets suspicious of Kee when she has a contraction on the bus to the coast:

Miriam: "Lord, give Kee the strength to know that she has the power already within her. She has the wisdom ..." Soldier: "What's wrong with you? I said, what's wrong with you? Look at me! I said, what's wrong with you?" Miriam: "Saint Gabriel, help us ..." Soldier: "Shut up!You! Out!” Miriam: "Saint Gabriel, come to our aid! Soldier: "Listen, you fucking nutcase! Get out! (01:09:2601:09:41).

In the face of danger, Miriam tries to buy time for Kee so that she will be safe and sound by reciting prayers while folding both of her hands, something that she always does. The hand gesture of praying itself is originated in what Sanskrit termed as Mudras, which was incorporated into the Christian teaching in the $4^{\text {th }}$ century, symbolizing human relationship with nature and Deity (Rajput, 2016). In the scene, Miriam seems very afraid, especially after the soldier hit her, yet she still puts her body as a shield for Kee, which also signals the theme of sacrifice.

\subsection{Jasper: Optimistic Spirituality}

With his long hair and his love for weed, the stereotypical appearance of Jasper utterly represents a hippie archetype, yet he is full of optimism and humor amidst apocalypse. As a foil character of Theo, Jasper's hilarity is his way of dealing with the gloominess of the post-apocalyptic world. He knows how to spread positivity around him, even though he is struggling himself as his wife is catatonic after the government tortured her in exchange for information about the beginning of infertility. Jasper's wife is a journalist, who is also a victim of disenchantment, where fascist behavior takes over her well-being in the name of being "nationalistic." Oftentimes, he talks about faith and hope, as seen in one of the scenes where he talks about how Theo and Julian's first meeting was brought by faith,

Everything is a mythical cosmic battle between faith and chance... So, you've got faith over here, right, and chance over there... Yeah, there you go. Julian and Theo met among a million protestors in a rally by chance. But they were there because of what they believed in the first place, their faith. They wanted to change the world. And their faith kept them together. But by chance, Dylan was born (00:53:28-00:54:22).

How he describes Theo and Julian's encounter portrays how meaningful faith is; as long as one has faith in their belief, amazing events will occur eventually. However, as optimistic as he has always been, in the face of despair, he is also a normal human being who has his doubts against the future's certainty, one of which is when he talks about a twisted event when Baby Dylan is killed in a flu pandemic as described as below:

Their faith put in praxis... Chance... He was their sweet little dream. He had little hands, little legs, little feet. Little lungs. And in 2008, along came the flu pandemic. And then, by chance, he was gone. You see, Theo's faith lost out to chance. So, why bother if life's going to make its own choices? (00:54:3500:55:15).

Jasper may not always be as positive as Miriam, but he knows how to keep holding on, even though it costs his and his loved ones' life. When Fishes approaches his house, he poisons his wife by giving her Quietus, the suicide kit that he believes will 
lessen his wife's pain rather than having her killed by the rebels (00:57:19). Meanwhile, he confronts the rebels with his usual comical acts by cracking a joke in front of Luke, who shots him later on (00:58:52). His sacrifice in protecting Miriam, Theo, Kee, and her baby, comes from his belief that they will make it to the Tomorrow boat eventually, which portrays how his spirituality emerges from vulnerability in the hope for tomorrow.

\section{CONCLUSION}

Unlike some Hollywood apocalyptic science fiction movies, Children of Men portrays how postapocalypse can be sensed through its realistic depiction that reflects today's world. After evaluating modern spirituality in the movie through aspects such as contextual background, symbolism, and mise-en-scène, it can be inferred that spirituality has transformed into various shapes. The 9/11 event has indeed resulted in negative perceptions towards religion, and through the movie, the representation of spirituality is not only what Spencer (2012) defined as a human's sense of meaning in the universe. Spirituality has become a double-edged sword that is very powerful yet dangerous, as seen from the scenes where Muslim protesters take over the streets in the name of their religion and how protesters in yellow trench coats urge the society to repent from their sins. However, the portrayal of Islam in the movie seems very stereotypical, which further hints at how Hollywood tends to put their thumb on the scale when it comes to certain religions. The phobia of unseen terrorists resulted from 9/11, has affected the film industry greatly, and no one knows when the depiction of Islam will get better. It is also worth mentioning that even though the depiction seems negative, it is a form of spirituality, nonetheless.

Analyzing characteristics of the already disenchanted society in the movie proves how religion cannot be separated from the postapocalyptic society, contradicting the assumption that we live in a secularized world (Berger et al., 1999). From Theo characterization, we can understand how spirituality is a complex concept that occurs to him as a trigger for re-enchantment, even though it seems implicit. Kee, on the other hand, is a symbol of the most important keys in the movie: faith and hope. Lastly, Miriam and Jasper are unique individuals with a unique spirituality. Their beliefs are not limited to one religion yet they have a strong faith in humanity, and they are willing to sacrifice themselves for others. Furthermore, the portrayal of the characters in the movie further suggests how the disenchanted society tries to re-connect with the world again, and modernity itself acts as a stimulus for re-enchantment (Jenkins, 2000). From the characterizations in the movie, modern spirituality can be inferred as a fusion of various divine energies that comes within each individual that enables them to relive and revive their lives in the face of apocalypse.

The movie contains implicit elements of spirituality through symbolism such as the "Tomorrow boat" that represents a new beginning, as well as explicit critiques through the representation of religion and the characters' dialogue that sheds light on their spirituality. The biblical apocalyptic narrative in the movie also implies how religion will always have an impact in the world, although it has developed into something different from religion in the Romantic era, in which a mythical pre-modern and un-rationalized imagining is more desirable (Jenkins, 2000). The impact is incorporated in what Peter L. Berger and his fellow scholars termed as desecularization, resulting in modernity that has aggravated significant movements that counter secularization. Thus, the spirituality portrayed in the movie is fairly different from how it was usually depicted in the past before 9/11 occurred, as seen from the characterization in the movie.

Most of apocalyptic science fiction movies in Hollywood utilize biblical apocalyptic narratives as the core of their plot, and it is very important for the audience to critically respond to how spirituality is being represented. The analysis of the chosen scenes and dialogues in Children of Men is evidence that an apocalyptic science fiction movie critically reflects today's society and can assess a crucial issue that emerges from it. Noting how this particular issue is often depicted in Hollywood films, it is important to explore the representation of modern spirituality in popular culture by conducting further research on the portrayal of the post-apocalyptic society and the behavior of its members.

\section{REFERENCES}

Barasch, M. (1997). The Language of Art: Studies in Interpretation. 65. New York: New York University Press.

Berger, P., Weiming, T., Sack, J., Weigel, J., Martin, D., Davie, G., An-Na'im, A. (2001). The Desecularization of the World: Resurgent Religion and World Politics. Sociology of Religion. P.L. Berger (Ed.). SOCIOL RELIG. 62. 10.2307/3712234.

Black, W. (2010). Beyond the End of the World 2012 and apocalypse. Lulu.com, 27.

Bordwell, D., \& Thompson, K. (2004). Film art: An introduction. Boston: McGraw-Hill.

Callahan, M. (2017). Weaponizing language: How the meaning of 'Allahu Akbar' has been distorted. Retrieved from 
https://news.northeastern.edu/2017/11/08/w eaponizing-language-how-the-meaning-ofallahu-akbar-has-been-distorted/

Chaudhary, Z. (2009). Humanity adrift: race, materiality, and allegory in alfonso cuarón's children of men. Camera Obscura, 24 (3 (72)): 73-109. https://doi.org/10.1215/02705346-2009010 .

Domingo, J. (2015). Liquid cinematography and the representation of viral threats in Alfonso Cuarón's "Children of Men" / Cinematografía líquida y la representación de amenazas virales en "Children of Men", de Alfonso Cuarón. Atlantis, 37(2), 137153. Retrieved from www.jstor.org/stable/24757787.

French, P. (2004). How to spook village people. The Guardian review. Retrieved from https://www.theguardian.com/theobserver/2 004/aug/22/features.review47.

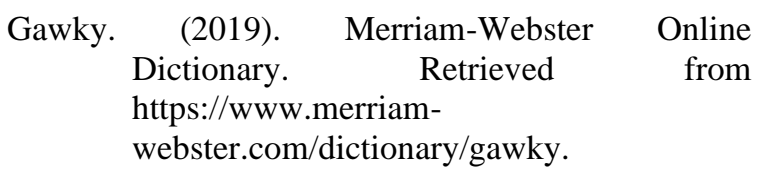

Hamner, M. (2015). Sensing religion in Alfonso Cuarón's "Children of Men." Religions, 6(4), 1433-1456. doi: 10.3390/rel6041433.

Healey, S. (2005). Religion and terror: A post-9/11 analysis. International Journal on World Peace, 22(3), 3-23. Retrieved from www.jstor.org/stable/20753495.

Jenkins, R. (2000). Disenchantment, enchantment and re-enchantment: Max Weber at the millennium. Max Weber Studies, 1(1), 1132. Retrieved from www.jstor.org/stable/24579711.

Meynell, H. (2011). Literature and Theology: New Interdisciplinary Spaces. H. Walton (Ed.). The Heythrop Journal, 52(6), 1081-1082. doi: 10.1111/j.1468-2265.2011.00699_39.x.

O'Donnell, M. (2015). Children of Men's ambient apocalyptic visions. Journal of Religion and Popular Culture, 27 (1), 16-30.

Rajput, S. (2016). The source, meanings, and use of "mudra" across religions. doi: 10.5281/zenodo.155343. Retrieved from https://www.researchgate.net/publication/30
8693036_The_Source_Meanings_And_Use _Of_Mudra_Across_Religions

Repent. (2019). Cambridge Online Dictionary. Retrieved from https://dictionary.cambridge.org/dictionary/ english/repent.

Riesman, A. (2016). Future shock: Director Alfonso Cuarón revisits Children of Men, his overlooked 2006 masterpiece, which might be the most relevant film of our dark new century. Retrieved from https://www.vulture.com/2016/12/childrenof-men-alfonso-cuaron-c-v-r.html.

Rotten Tomatoes. (n.d.). Retrieved from https://www.rottentomatoes.com/m/children _of_men.

Schwartzman, S (2016). Children of men and a plural messianism, Journal of Religion \& Film: (13) 1, Article 1, 3.

Spencer, M. (2012). What is spirituality? A personal exploration. Retrieved from https://www.rcpsych.ac.uk/docs/defaultsource/members/sigs/spiritualityspsig/what-is-spirituality-maya-spencerx.pdf?sfvrsn=f28df052_2.

Swartz, Z. (2009). Ever is no time at all: theological issues in post-apocalyptic fiction and cormac mccarthy's the road. (master's thesis). Retrieved from Georgetown Library Repository https://repository.library.georgetown.edu/bit stream/handle/10822/553396/swartzzachary .pdf? sequence $=1$.

Taylor, M. (2007). After God. Bibliovault OAI Repository, the University of Chicago Press.

10.7208/chicago/9780226791722.001.0001.

Weber, M. (1963). The Sociology of Religion. Boston: Beacon Press.

Woolley A. (2014) States of Belonging: Alfonso Cuarón's Children of Men. In: Contemporary Asylum Narratives. London: Palgrave Macmillan. 